\title{
EFFECTS OF CERTAIN INSECTICIDES ON EGGS OF SPODOPTERA LITTORALIS
}

\author{
HANAN, S. ABD-EL-AZIZ and SAMYA Z. SAYED
}

Plant Protection Res. Inst., ARC, Dokki, Giza, Egypt.

(Manuscript received 15 December 2013)

\begin{abstract}
Seven chemical insecticides were tested for their ovicidal activity against Spodoptera littoralis eggs, using two methods, namely dipping of tafla leaves containing 0-1 day old eggs and o-day old eggs were deposited on insecticide residues on tafla leaves. Rynaxypyr was the most promising. It was taken as the standard insecticide and given an arbitrary index value of 100 units, when $0-1$ day old eggs were treated directly by dipping in insecticide solution. As for the indirect ovicidal activity, emamectin benzoate came first and was given arbitrary index value of 100 units. On the other hand spinetoram, in comparison showed the least indirect ovicidal effect.

Regarding the inhibitory action, it was obvious that rynaxypyr and indoxacarb exhibited high inhibitory activity $(100 \%)$ in suppressing the number of deposited eggs when moths were subjected to $100 \mathrm{ppm}$ and it was followed closely by pyridalyl, emamectin benzoate and spinetoram being 97.8, 97.0 and 95.3\%, respectively. However, all insecticides showed variable degrees of inhibition at the least concentration tested $(0.1 \mathrm{ppm})$, except spinosad and spinetoram having no inhibition activity for deposited eggs.

Key words: Spodoptera littoralis, ovicidal activity, egglaying inhibition, novel insecticides.
\end{abstract}

\section{INTRODUCTION}

The cotton leafworm Spodoptera littoralis (Boisd.) is considered the most serious and destructive cotton pests and other agronomic as well as vegetable crops in Egypt (Magd El-Din \& El-Gengaihi, 2000). It is also proved to be an important pest of cotton in Africa, Middle East and Southern Europe.

Pest management programs for combating such pest up till year 2000 was directed mainly for hand picking egg-masses early in the season by children and to implement the application of insecticides purposely for their larvicidal activities laterly.

However, due to the recent universal announcement of childhood rights, using of children in collecting egg-masses is forbidden and restricted by law. Therefore, it was felt necessary find out newly developed compounds using as ovicidal action in addition to their well known larvicidal activity seemed to have some potential as a solution to the lack of labors collecting $S$. littoralis egg-masses. 
Identification of pesticides possessing ovicidal activity, belonging, to organophosphorus, carbamate and synthetic pyrethroids had received extensive attention either against S. littoralis (Mitri and Kamel, 1970, Ascher and Nemny, 1974, Abo Elghar et al., 1976, Abo-Elghar et al., 1980, El-Guindy et al., 1976, Radwan et al., 1985)., and other investigators working against other insect pests (Abd El-Megeed et al., 1987, Joginder et al., 1993, Charmillot et al., 2001, Baiteau and Noronha, 2007, Charmillot et al., 2007, El-Barkey et al., 2009, El-Saeed et al., 2009).

There are few studies regarding the ovicidal effect of novel insecticides on eggs of lepidopteran pests and most reports have been focused on the control of larval stage, therefore little information is available about the effect of novel groups of insecticides on eggs of $S$. littoralis, particularly those of low risk.

Therefore, it was important to test the effectiveness of these novel insecticides, either registered those under investigation, at different concentrations against egg masses and moths of $S$. littoralis laboratory strain.

\section{MATERIALS AND METHODS}

\section{Test insect}

The test insect, cotton leafworm Spodoptera littoralis (Bosid.) was reared in the laboratory at $25 \pm 2{ }^{\circ} \mathrm{C}$ and $60 \pm 5 \%$ R.H. according to El-Defrawi et al., (1964) technique, feeding on castor bean Ricinus communis (L.) leaves. Egg stage (0-1 day old) and newly emerged adult stage were used in the present study for estimating the direct and indirect ovicidal activity of seven novel insecticides.

\section{Insecticides tested}

The seven novel insecticides tested includes: pyridalyl (5-1812, 50\% EC) Sumitomo Chemical Co., Ltd, rynaxypyr (Coragen 20\% SC) Du Pont, indoxacarb (Avaunt 15\% SC) Du Pont, emamectin benzoate (Radical 1.9\% EC) Agromen Chemical Co. Ltd, spinosad (Tracer 24\% SC) Dow Agro Science, methoxyfenozide (Runner 24\% $\mathrm{SL}$ ) Rohm and Haas Co., spinetoram (Radiant 12\% SC) Dow Agro Science.

A stock solution $(W / V)$ of each tested formulated insecticide was freshly prepared as aqueous solution and diluted serially by water to obtain seven progressive concentrations ranging from 100 to $0.1 \mathrm{ppm}$.

\section{Ovicidal experiments}

\section{a- Direct ovicidal effectiveness (curative)}

Egg-masses of uniform age ( $0-1$ day old) were obtained by copulating females and males together in big glass jar $2 \mathrm{~kg}$ equiped with tafla branches as ovipositional site and cotton pad soaked in $10 \%$ sugar solution for feeding. 
Newly deposited egg-masses of uniform age (0-1 day old) were obtained after starting oviposition in the rearing colony. The upper layers of egg-masses were removed gently under the binocular in order to count the number of eggs in the remaining lower layer, which was divided into patches, each contained about100 eggs.

In all cases, three replicates each of 5 egg-masses were used for each concentration. The leaves of tafla with eggs (0-1 day old) were immersed for 5 seconds in each concentration. The treated egg-masses were allowed to dry and then placed in $15 \mathrm{~cm}$ diam. petri-dishes (5 egg- mass/dishes) and held at $25 \pm 2{ }^{\circ} \mathrm{C}$ for hatching. Similar number of water-treated glass jars provided with water-treated tafla leaves were prepared to provide 0-1 day old egg-masses used as a control. Daily inspection was made till 2 days after the water treated eggs of check hatch.

Once all eggs in control experiment had hatched out, the eggs in treatments were observed under binocular and the rate of hatching were recorded.

\section{b- Indirect ovicidal effectiveness (preventive)}

In the laboratory, branches of tafla, Nerium oleander were used as site for eggs deposition, they were dipped in aqueous solution of the tested insecticides at different concentrations and then left to dry under laboratory conditions. Also $1 \mathrm{Lb}$. glass jars were internally coated with the same concentrations. Once both tafla branches and treated glass jars dry, three replicates, each of 2 males and 3 females moths were allowed to mate in each pre-coated jar, provided with treated tafla as a site for eggs laying. The egg-masses were collected daily till death of moths and transferred to clean Petri-dish.

\section{c- Calculations and statistical analysis}

Daily inspection for petri dishes was carried out till 2 days after the water-treated check hatch. Unhatchability percentages were recorded for each tested conc. /insecticide. Unhatched percentages of eggs representing eggs mortalities were corrected according to natural mortality in check treatment using Abbott's(1925) formula and the corrected unhatchability percentages were subjected to statistical analysis according to Finney (1971) and consequently $L C_{50}$ values, were computed and used for calculating the toxicity index (Sun, 1950) which was used for comparing the relative toxicity of insecticides used.

\section{d- Inhibitory activity for egg-laying}

For studying the inhibitory activity for each insecticide, the total number of eggs deposited in each concentration/ insecticide were calculated and compared as relative to untreated check to obtain the percent of reduction in number than check (inhibitory action). 


\section{RESULTS AND DISCUSSION}

\section{1- The curative ovicidal activity}

The curative ovicidal action of seven insecticides belonging to novel groups against $0-24$ hrs old eggs of the laboratory strain of Spodoptera. littoralis is represented in Table (1). According to toxicity index values calculated on the basis of $\mathrm{LC}_{50}$ values obtained on $0-24 \mathrm{hr}$ old eggs Rynaxypyr the most effective compound was taken the standard insecticideand give the arbitrary index value of 100 followed by relatively lower toxicity index value $(13.52 \%)$ for indoxacarb and then methoxyfenozid (5.31\%). By comparison, the other four insecticides produced extremely low activity recording toxicity index values of $1.21,1.0,0.84$ and $0.36 \%$ for spinosad, emamectin benzoate, spinetoram and pyridalyl, respectively as the effectiveness of rynaxypyr against the 1-day old eggs deposited by S.littoralis. Furthermore, the relative potency level can be used as a convenient method in comparing the degree of toxicity of the different compounds in this study. The potency levels of the tested insecticides are expressed as number of folds, at the required toxicity level, compared with the least efficient toxicant included in the evaluation in the study.

Concerning the relative potency levels based on the $L C_{50}$ values as represented in Table (1), the ovicidal activity values of Rynaxypyr, indoxacarb, emamectin benzoate, spinosad, methoxyfenozid and spinetoram were 271.4, 36.71, 2.74, 3.29, 14.42 and 2.28 times as toxic as the ovicidal action of pyridalyl, respectively against the egg masses deposited by $S$. littoralis.

Table 1. Direct (curative) ovicidal effectiveness of seven novel insecticides applied by dipping technique on $0-24 \mathrm{hr}$ old egg-masses of $S$. littoralis (Bosid.).

\begin{tabular}{|c|c|c|c|c|c|c|}
\hline Insecticide & $\begin{array}{c}\text { Conc. tested } \\
\text { range( ppm) }\end{array}$ & Slope $\pm \mathrm{SE}$ & $\mathrm{LC} 50$ & $95 \% \mathrm{CL}$ & $\begin{array}{c}\text { Toxicity } \\
\mathrm{ppm}\end{array}$ & $\begin{array}{c}\text { Relative } \\
\text { Potency }\end{array}$ \\
\hline Pyridalyl & $0.1-100$ & $0.763 \pm 0.08$ & 7.60 & $3.94-15.52$ & 0.36 & 1 \\
\hline Rynaxypyr & $0.1-100$ & $0.316 \pm 0.05$ & 0.028 & $0.001-0.127$ & 100 & 271.4 \\
\hline Indoxacarb & $0.1-100$ & $0.767 \pm 0.11$ & 0.207 & $0.041-0.530$ & 13.52 & 36.71 \\
\hline Emamectin b. & $0.1-100$ & $0.990 \pm 0.18$ & 2.776 & $0.903-7.925$ & 1.00 & 2.74 \\
\hline Spinosad & $0.1-100$ & $0.851 \pm 0.14$ & 2.310 & $0.602-6.493$ & 1.21 & 3.29 \\
\hline Methoxyfenozid & $0.1-100$ & $0.626 \pm 0.05$ & 0.527 & $0.269-0.895$ & 5.31 & 14.42 \\
\hline Spinetoram & $0.1-100$ & $0.581 \pm 0.05$ & 3.335 & $1.793-5.942$ & 0.84 & 2.28 \\
\hline
\end{tabular}

$\mathrm{CL}$ : confidential limit

Sun's toxicity index $=\mathrm{LC}_{50}$ or $\mathrm{LC}_{90}$ of the most toxic compound/ $\mathrm{LC}_{50}$ or $\mathrm{LC}_{90}$ of the tested compound $\mathrm{x} 100$ Relative Potency $=\mathrm{LC}_{50}$ of the least toxic compound/ $\mathrm{LC}_{50}$ of the tested compound 
The results are accordance with those published Bassi et al., (2009) they found that rynaxypyr (Coragen) exhibited strong ovicidal and larvicidal activity. However, the most promising findings were obtained when Coragen (rynaxypyr) was applied before egg-hatch, during embryonic stage of codling moth. The ovicidal timing (egg-laying to black-head stage) provides the highest overall performance against codling moth. This is explained by the long lasting biological availability of the molecule, the partial ovicidal effects, the potent ovicidal effects and the strong larvicidal activity on codling moth neonates, either by contact or ingestion.

In this field of study Mahmoud et al., (2011) found that all eggs of Plutella xylostella were killed by dose of $1000 \mathrm{mg} / \mathrm{L}$ of pyridalyl, spinosad and hexaflumuron and the mortality of eggs was enhanced as the concentrations increased.

As for spinosad compounds the obtained results are going in line with those obtained by Temerak (2005) who found that spinosad (Spintor 24 SC) produced $100 \%$ initial mortality of the fresh natural egg masses of $S$. littoralis during and after hatching.Temerak (2007) reported that spinetoram (Radiant 12\% SC) was 5 and 7 times stronger than spinosad for control the cotton leafworn in the field and laboratory respectively. However, the high toxicity of spinosad on lepidopterous eggs was also supported by Baiteau and Noronha (2007) findings against the European corn borer, Ostrinia nubilalis.

As for pyridalyl the results are inagreement with Ishayama et al., (2005) who reported that the efficacy of pyridalyl at $100 \mathrm{mg} / \mathrm{ml}$ on eggs of Orius stringicollis was lower than 20\%. Recent results of Venkateswari et al., (2008) revealed that the $\mathrm{LC}_{50}$ values of abamectin and emamectin benzoate for ovicidal action against 1 day old egg batches of $S$. littoralis by dip method were 2.0 and $0.1 \mu \mathrm{g} \mathrm{ml}^{-1}$.

\section{Preventive ovicidal activity}

Results of the preventive (indirect) ovicidal activity when $S$. littoralis eggs were laid directly on residues of the chosen concentrations of the tested insecticides are shown in Table (2). Toxicity index calculated on the basis of $\mathrm{LC}_{50}$ for each insecticide revealed that emamectin benzoate exhibited the highest preventive ovicidal action and given arbitrary value of 100 units. The effectiveness of other insecticides varied considerably, where indoxacarb, pyridalyl and methoxyfenozide exhibited moderate preventive ovicidal activity recording toxicity index of $68.85,37.38$ and $33.42 \%$, respectively. The other three insecticides gave relatively less $\mathrm{LC}_{50}$ values that were spread out over a fairly wide range of concentration from $0.445 \mathrm{ppm}$ for rynaxypyr to $1.299 \mathrm{ppm}$ for spinetoram, resulted in toxicity index of 28.31 to $9.29 \%$, respectively. 
Table 2. Preventive (indirect) ovicidal effectiveness of seven novel insecticides for egg-masses deposited after exposure of $S$. littoralis moths to surfaces (tafla and glass) treated with the tested insecticides.

\begin{tabular}{|c|c|c|c|c|c|c|}
\hline Insecticide & $\begin{array}{c}\text { Conc. } \\
\text { Tested } \\
\text { range } \\
(\mathrm{ppm})\end{array}$ & Slope $\pm \mathrm{SE}$ & $\mathrm{LC} 50$ & $95 \% \mathrm{CL}$ & Toxicity & RelativeP \\
index & otency \\
\hline Pyridalyl & $0.1-100$ & $0.669 \pm 0.18$ & 0.337 & $0.002-2.072$ & 37.38 & 3.85 \\
\hline Rynaxypyr & $0.1-100$ & $0.850 \pm 0.10$ & 0.445 & $0.187-0.798$ & 28.31 & 2.92 \\
\hline Indoxacarb & $0.1-100$ & $0.904 \pm 0.15$ & 0.183 & $0.031-0.421$ & 68.85 & 7.1 \\
\hline Emamectin b. & $0.1-100$ & $0.964 \pm 0.08$ & 0.126 & $0.093-0.163$ & 100.00 & 10.31 \\
\hline Spinosad & $0.1-100$ & $0.725 \pm 0.11$ & 0.537 & $0.138-1347$ & 23.46 & 2.42 \\
\hline Methoxyfenozid & $0.1-100$ & $1.155 \pm 0.27$ & 0.377 & $0.038-1.195$ & 33.42 & 3.45 \\
\hline Spinetoram & $0.1-100$ & $1.781 \pm 0.10$ & 1.299 & $1.137-1.486$ & 9.69 & 1 \\
\hline
\end{tabular}

CL: confidential limit

As shown in Table (2), the relative potency based on the $\mathrm{LC}_{50}$ values, the ovicidal effectiveness values of pyridalyl, rynaxypyr , indoxacarb, emamectin benzoate, spinosad, and methoxyfenozid were 3.85, 2.92, 7.10, 10.31, 2.42 and 3.45 folds as the ovicidal efficacy of spinetoram, respectively against egg masses produced from moths and deposited on treated tafla with different concentrations of the aforementioned insecticides

On the contrary, Bassi et al., (2009) indicated that Coragen demonstrated highly activity on the different leafminers species affecting the pome fruits when applied during the egg-laying before the mines are visible on leaves. Also, they indicated that the ovicidal effects are enhanced when eggs of Cydia pomonella are laid on treated surfaces.

Recently Amer et al., (2012) found that emamectin benzoate was more effective on 1-day old eggs of Tuta absoluta than pyridalyl. Also, similar results was obtained when both compound were tested against 1-day old eggs Pectinophora gossypiella (saund.).

Data in Table (3) showed the inhibiting activity of egg-laying of the tested insecticides when eggs were laid directly on insecticidal residues, expressed as reduction percentages in the number of eggs deposited on treated surfaces of tafla plant or/and glass vials. However it is clearly evident that the most pronounced percent of reduction in eggs deposition at 100 ppm has been achieved in indoxacarb, rynaxypyr recording $100 \%$ for both and was followed closely by pyridalyl, emamectin 
benzoate and spinetoram, recording $97.85,97.02$ and $95.38 \%$ inhibition, respectively. In the meantime three insecticides, i.e., pyridalyl, emamectin benzoate and indoxacarb are still effective lately at the lower concentration tested $(0.1 \mathrm{ppm})$ and recording relatively higher recognized inhibitory activity of $80.74,74.71$ and $72.39 \%$ reduction, respectively. In contrast, spinosad seemed to be the least active in its indirect ovicidal activity at all concentrations tested, recording $45.28-Z e r o \%$ inhibition for concentrations ranged between 100 and $0.1 \mathrm{ppm}$.

Table 3. The inhibitory activity of seven novel insecticides on Spodoptera littoralis egglaying after exposure of moths to treated surfaces of tafla leaves and internally coated glass jars.

\begin{tabular}{|c|c|c|c|c|c|c|c|}
\hline \multirow{2}{*}{ Treatment } & \multicolumn{6}{|c|}{ \% Inhibition of deposited eggs at indicated cone. (ppm) } \\
\cline { 2 - 9 } & 100 & 50 & 10 & 5 & 1 & 0.5 & 0.1 \\
\hline Pyridalyl & 97.85 & 95.53 & 94.38 & 93.22 & 90.82 & 83.38 & 80.74 \\
\hline Rynaxypyr & 100 & 91.32 & 82.32 & 62.52 & 61.62 & 44.18 & 31.26 \\
\hline Indoxacarb & 100 & 90.66 & 84.87 & 82.39 & 82.33 & 75.95 & 72.39 \\
\hline Emamectin b. & 97.02 & 92.89 & 91.32 & 90.66 & 88.51 & 78.67 & 74.71 \\
\hline Spinosad & 45.28 & 36.36 & 25.45 & 20.33 & 16.85 & 9.91 & -- \\
\hline Methoxyfenozid & 86.14 & 82.94 & 81.34 & 71.22 & 65.18 & 62.87 & 59.85 \\
\hline Spinetoram & 95.38 & 78.86 & 76.37 & 73.17 & 67.14 & 44.05 & -- \\
\hline
\end{tabular}

The results are accordance with those published by Mohamed et al., (2009) who found that avermectin (methylamine-avermectin) exhibited potential effect on the fecundity of Collosobruchus maculatus females and resulted in reduction (inhibition) of the deposited eggs number. Also they found that hatching rate of eggs decreased dramatically as the concentration of avermectin increased.

However, our results elucidate in general that the application of the ovicides must take into consideration not only the direct effect (curative) on eggs but also the indirect (preventive) influence on eggs deposition later, specially when these insecticides were used too early at starting of egg laying period.

\section{REFERENCES}

1. Abbott, M.S. 1925. A method of computing effectiveness of an insecticides. J. Econ. Entomol., 18: 265-267.

2. Abo-Elghar, M.R., I.A. El-Keie, S.H. Mitri and H.S.A. Radwan 1980. Field evaluation of certain insecticides for ovicidal activity of the cotton leafworm Spodoptera littoralis (Boids.). Z. Ang. Ent. 89: 100-104. 
3. Abo-Elghar, M.R., H.S.A. Radwan and I.M.A. Ammar. 1976. The ovicidal effect of an chitin biosynthesis disrubtor on Spodoptera littoralis egg-masses. The $3^{\text {rd }}$ Pest Cont. Conf. Ain Shams Univ., Egypt.

4. Abd El-Megeed, M. I., W. M. Watson, Z. H. Zidan , G.M. Hegazy and N.M. Hussein. 1987. The ovicidal effectiveness of synthetic insecticides and insect growth regulators against the spiny and pink bollworms (Medlingen Van de Facultat, Landbouw. Wetenschappen-Rijks Univ., 32 (2b): 495-499.

5. Amer, R.A.M., A.E. Hatem and A.M. Adly. 2012. Effect of emamectin benzoate and pyridalyl on some demographic aspects of the pink bollworm, Pectinophora gossypiella (Saunders). Egypt J. Agric. Res., 90 (2): 657-673.

6. Ascher, K.R.S. and N.E.Nemny 1974. The ovicidal effect of PH-6040 (1-(4chlorophenyl)-3-(2,6-difurobenzoyl)-urea) in Spodoptera littoralis (Boids.) Phyto, 2: 131-133.

7. Bassi, A., J.L. Rison and J.A. Wiles. 2009. Chlorantrantiprole (DPX-E2Y45, Rynaxypyr, Coragen), a new diamid insecticide for control of codling moth (Cydia pomonella), Colorado potato beetle Leptinatarsa decemlineata) and European grapevine moth (Lobesia botrana), Zbornik predavaanj in refratov, slovenskega posvetovanja ovarstvu rastlin z mednarodno udelezbo Nora Gorica, 4-5 marec, 2009.

8. Baiteau, G. and C. Noronha. 2007 . Topical, residual and ovicidal contact toxicity of three reduced-risk insecticides against the European corn borer, Ostrinia nubilalis (Lep.: Crambidae) on potato. Pest Manag. Sci., 63: 1230-1238.

9. Charmillot, P.J., A. Gourmelon, A .L. Faber and D. Pasquier. 2001. Ovicidal and larvicidal effectiveness of several insect growth inhibitor and regulators on the codling moth Cydia pomonella L. (Lep., Tortricidae). J. Appl. Ent., 125: 147-153.

10. Charmilot, P.J., D.A. Pasquier, C.S. Salamin and T.A. Hovannesyan. 2007. Ovicidal and larvicidal effectiveness of insecticides applied by dipping apples on the small fruit tortrix, Grapholita loberzewskii, Pest Manag. Sci., 63 (7): 677-681.

11. El-Barkey, N.M., A.E. Amer and M.A. Kandeel. 2009. Ovicidal activity and biological effect of radiant and hexaflumuron against eggs of pink bollworm, Pectinophora gossypiella (Saund) (Lepi.: Gelechidae). Egyptian Acad. J. Biol. Sci., 2: 23-36.

12. El-Defrawi, M., E. Toppozada, N. Mansour and M. Zeid. 1964. Toxicological studies on the Egyptian cotton leafworm Prodenia litura, J. Econ. Entomol., 57: 591-593.

13. El-Guindy, M.A.,S.M. Madi and M.M. El-Sayed. 1976. The ovicidal action of insecticides and insect growth regulators on eggs of susceptible and resistant strains of the Egyptian cotton leadworm Spodoptera littoralis (Boids.), Bull. Ent. Soc. Egypt, Econ. Ser., 10: 285-292. 
14. El-Saeed, E.H., S.A. El-Mahy and N.N. Hassan. 2009. Toxicological studies of some insecticides against the pink bollworm, Pectinophora gossypiella (Saund.), Bull. Ent. Soc. Egypt, Econ. Ser., 35: 203-222.

15. Finney, D.J. 1971. Probit analysis $3^{\text {rd }}$ Ed. Cambridge University Press. Cambridge, United Kingdom.

16. Ishayama, S., S. Saito, K. Kuroda, K. Umeda and K. Kasamatsu. 2005. Pyridalyl,a novel insecticide: Potency and insecticidal activity. Arch. Insect Biochem. and Physio, 58: 226-233.

17. Joginder, S., J.S. Gilli and S. Jasbir. 1993. Ovicidal of insecticides on eggs of gram podborer Helicoverpa armigera and spotted bollworm Earias insulana, Indian J. Agri. Sci., 63: 853-855.

18. Magd El-Din and S.E. El-Gengaihi. 2000. Joint action of some botanical extracts against the Egyptian cotton leafworm, Spodoptera littoralis (Boids.), Egypt. J. Biol. Pest Cont., 10 (1): 51-56.

19. Mitri, S.H. and A.A.M. Kamel. 1970. The ovicidal effect of certain newer insecticides on Spodoptera littoralis egg-masses. J. Econ. Entomal. 63: 676-678.

20. Mohamed, H.A., O.A. El-Sebai and S.F. Hafez. 2009. Effect of lufenuron and methylamine avermectin on growth, development and reproductive performance of Callosobruchus maculates (F.) (Coleoptera: Bruchidae) Bull. Ent. Soc. Egypt, Econ. Ser., 35: 75-90.

21. Mahmoud Vand, M., A.S. Garjan and H. Abbasipour. 2011. Ovicidal effect of some insecticides on the diamondback moth, Plutell xylostella (L.) (Lepidoptera: Yponomeutidae) Chilen J. Agric. Res., 71 (2): 226-230.

22. Radwan, H.S.A., O.M. Assal and M.A. Samy. 1985. Ovicidal action: potentiation of synthetic pyrethroids by insect growth regulators against the cotton leafworm Spodoptera littoralis (Boids.), Bull. Ent. Soc. Egypt, Econ. Ser., 14: 275-283.

23. Sun, Y.P. 1950. Toxicity index, an improved method of comparing the relative toxicity of insecticides, J. Econ. Ent., 43: 45-53.

24. Temerak, S.A. 2005. Ovicidal activity of the natural bio-product spinosad through field observation of tagged egg masses of Spodoptera littoralis on cotton in five Governorates of Egypt Assiut J. Agric. Scie., 36 (1): 85-95.

25. Temerak, S.A. 2007. Susceptibility of Spodoptera littoralis to old and new generation of spinosyn products in five cotton Governorates in Egypt. Resistance Pest Management Newsletter, 16 (2): 18-21.

26. Venkateswari, G., P.V. Krishnayya, P. Arjuna Rao and KVM Kishna Murthy. 2008. Bioefficacy of abamectin and emamectin benzoate against Spodoptera littoralis (F.) Pest. Res. J., 20 (2): 229-233. 


\section{دراسات لبعض المبيدات على بيض دودة ورق القطن \\ حنان صليق عبد العزيز - سامية زين سيد \\ معهر بحوث وقاية النباتات - مركز البحوث الزراعية - الدقى جيزة.}

تم اختبار كفاءة سبع مبيدات لتقيمها كمبيدات ضد بيض دودة ورق القطن بطريقتين احدها مباثرة واخري غير مباشرة:

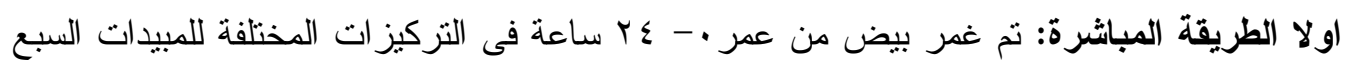

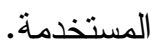
ثاتيا الطريقة غير المباشرة: وذلك بمعامله سطح البرطمانات من الداخل و ايضا اوراق التفله (اماكن وضع البيض) بالتركيز ات المختلفة للمبيدات السبع المستخدمة (التأثير المتنقى).

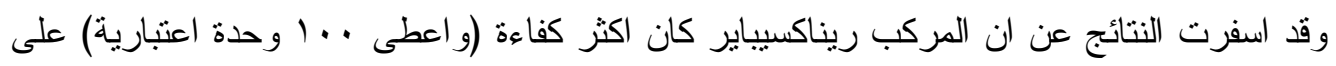
البيض و الذى تم معاملته مباشرة عن طريق الغمر ثم تبعه اندوكساكارب ثم ـ ميثوكسى فينوز ايد

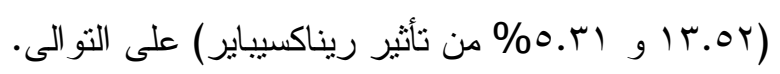

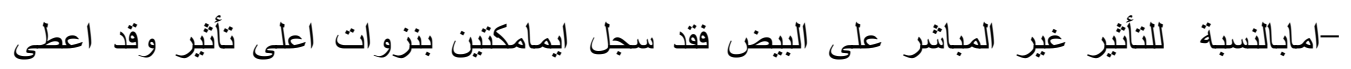

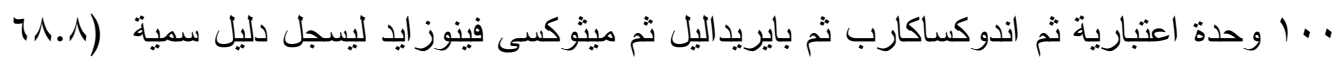

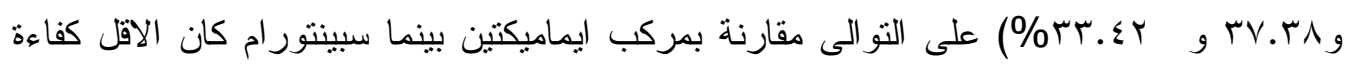
ليسجل دليل سمية ( 9.79 \% 9.9 \%) -امابالنسبة للنأثير المثبط على وضع البيض الناتج من وضعه على تفلة معاملة فقد كان ريناكسيباير

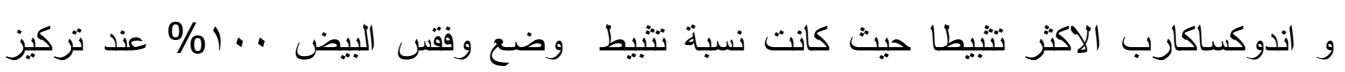

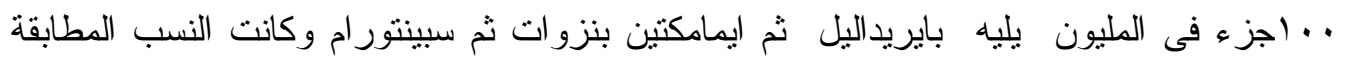

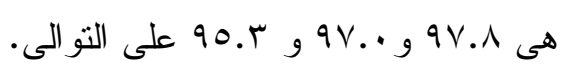

وقد سجلت المبيدات المستخدمة درجات متفاوتة عند المعاملة بتركيز ا.. جزء وهى فى المليون ماعدا

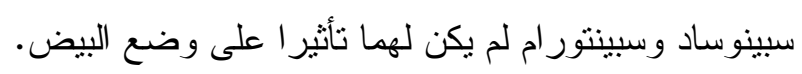

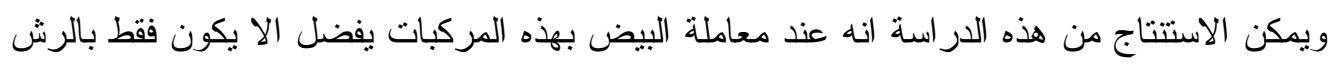

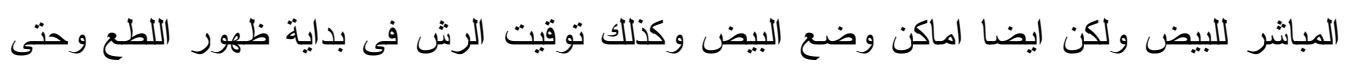

